\title{
ДИСКУРСИВНЫЙ МАРКЕР «ТО БИШЬ»: ПРИМЕР РАННЕЙ ПРАГМАТИКАЛИЗАЦИИ И СОВРЕМЕННОЕ ФУНКЦИОНИРОВАНИЕ
}

\author{
К. М. Шилихина, И. А. Ткач \\ Воронежский государственный университет
}

\section{THE RUSSIAN DISCOURSE MARKER "TO BISH" ("THAT IS"): EARLY PRAGMATICALIZAION AND MODERN USAGE}

\author{
K. M. Shilikhina, I. A. Tkach \\ Voronezh State University
}

\begin{abstract}
Аннотация: в статье рассматривается функиионирование дискурсивного маркера «то бишь». Смомента своего появления в письменной речи «то бишь» употребляется как прагматикализованная единииа, основной функцией которой является объяснение или уточнение сказанного ранее. Несмотря на то, что лексикографы описывают «то бишь» как просторечную языковую единицу, данные корпуса показывают, что она употребляется не только в устной речи, но и в письменных текстах различных жанров. Появление «то бишь» в высказывании означает, что говорящий осуществляет повторную референцию или еще раз характеризует объект, выбирая при этом другие языковые средства. В статье историческая динамика использования маркера «то бишь» анализируется по семи хронологическим срезам с опорой на данные Национального корпуса русского языка. Основная цель анализа - показать, как менялась функциональная нагрузка на данный маркер с течением времени, и объяснить, что заставляет говорящего повторно называть или описывать один и тот же объект и какие семантические компоненты акиентируются в результате повторной номинации или описания объекта. Анализ употреблений дискурсивного маркера «то бишь» позволяет делать выводы о том, как говорящие осуществляют референцию и как подбирают альтернативные способы номинации, часто - с учетом интересов адресата.

Ключевые слова: языковой корпус, дискурсивный маркер, референция, самокоррекция.
\end{abstract}

\begin{abstract}
Russian discourse marker "to bish" ("that is"). From the moment of its appearance in written texts, "to bish" is used as a pragmaticalized unit, the main functions of which is the introduction of explanation or elaboration on the previous part of the utterance. Lexicographers describe "to bish" as a substandard form; however, the analysis of corpus data demonstrates its active use not only in spoken discourse, but also in texts of various genres. The appearance of "to bish" in an utterance means that the speaker makes an alternative reference to or describes an object or a situation in different words. Historical dynamics of the use of the discourse marker "to bish" was analyzed across seven chronological strata. The data was obtained from the Russian National Corpus. The main aim of the analysis is to show the dynamics of functional load on the marker and to explain what makes the speaker use alternative ways of reference in on utterance. The paper also discusses semantic relations between two references or alternative descriptions in the utterance. The analysis of corpus data allows us to make conclusions about referential choices of speakers, which are often made in the interests of the addressee.
\end{abstract}

Key words: language corpus, discourse marker, reference, self-correction.

\section{Введение}

Проблема формирования дискурсивных маркеров активно обсуждается в современной лингвистике

(С Шилихина К. М., Ткач И. А., 2020
[1-4]. Такой интерес объясняется, во-первых, интересом к роли данных единиц в смысловой организации дискурса. Во-вторых, на материале дискурсивных

Контент доступен под лицензией Creative Commons Attribution 4.0 License.

The content is available under Creative Commons Attribution 4.0 License. 
маркеров лингвисты исследуют процессы грамматикализации и прагматикализации языковых единиц, в том числе в диахронической и типологической перспективе [5-8]. Общая картина складывается в результате обобщения данных о функционировании дискурсивов в разных языках, модусах дискурса и типах текстов.

Данная работа посвящена корпусному анализу дискурсивного маркера то бишь, семантика которого позволяет относить его к группе языковых средств, с помощью которых говорящие объясняют или уточняют сказанное ранее. Появление то бишь в высказывании означает, что говорящий осуществляет повторную референцию или еще раз описывает объект, выбирая при этом другие языковые средства, ср.:

Вот почему сельский зам. директора с корочками хочет работать с продажсами (то бишь торговым представителем)? [коллективный. Форум: Были вы в стране преподаваемого языка? (2008-2011)]

К тому же невоздержанность, то бишь обильные возлияния, несколько снижает эффективность анальгетиков. [Елизавета Кольцова. Наркоз: страхи и реальность (2002) // «100\% здоровья», 2002.11.11]

Приведенные примеры показывают, что говорящие нарушают принцип экономии, повторно говоря о том, о чем уже было сказано, причем повторная референция осуществляется сразу же после первого упоминания объекта или явления, т. е. когда называемый объект активирован в оперативной памяти адресата. Возникает вопрос, какие причины заставляют говорящего еще раз говорить о том, что уже известно собеседнику или читателю. Кроме того, интересны семантические изменения, которые происходят в высказывании в результате введения повторной номинации или характеристики объекта.

Данные вопросы позволяют сформулировать цель исследования следующим образом: необходимо показать, как менялась функциональная нагрузка на дискурсивный маркер то бишь с течением времени, и объяснить, что заставляет говорящего повторно называть или описывать один и тот же объект и какие семантические компоненты акцен- тируются в результате повторной номинации или описания объекта.

Данное исследование проведено на материале основного подкорпуса Национального корпуса русского языка [9], в котором содержится 924 контекста с дискурсивным маркером то бишь.

\section{Историческая динамика семантики дискурсивного маркера то бишь по данным НКРЯ}

Этимология частицы бишь в словаре М. Фасмера [10] описывается следующим образом: бишь - это аллегровая форма баешь от баю «говорю». М. Фасмер отмечает, что выражения, указывающие на речь другого, «ты говоришь, он говорит, говорил» часто подвергаются полному фонетическому преобразованию в речи.

В Толковом словаре В. И. Даля частица бишь описывается следующим образом: «частица, вставляемая в речь вопросительно, припоминая забытое, или || поправляясь, когда обмолвишься» [11].

В толковом словаре Т. Ф. Ефремовой частица бишь имеет помету просторечн. Толкование достаточно краткое: «Употребляется при выражении припоминания чего-либо» [12].

Таким образом, в словарях данная частица на протяжении двух веков устойчиво описывается либо как сигнал припоминания, либо как маркер самокоррекции. Далее посмотрим, как функционирует данная частица в составе дискурсивного маркера то бишь с 1700 г. до наших дней, сохраняет ли дискурсив те же функции припоминания и самокоррекции или развивает новые.

Исследование функционирования дискурсива то бишь с 1700 по 2014 г. было проведено по семи хронологическим срезам с шагом в 50 лет. Выделение двух последних хронологических срезов (1950-1985 гг. и 1986-2014 гг.) объясняется резкими переменами, которые произошли в современном русском языке в середине 1980-1990 гг. Данные об абсолютной и относительной частоте употребления маркера то бишь в разные хронологические периоды приведены в табл. 1.

Т а бл и ц а 1

Частота употребления дискурсивного маркера то бишь с 1700 по 2014 2. по данным основного подкорпуса НКРЯ

\begin{tabular}{|c|c|c|c|c|}
\hline Период & $\begin{array}{c}\text { Кол-во документов } \\
\text { в подкорпусе }\end{array}$ & $\begin{array}{c}\text { Кол-во документов, в которых } \\
\text { употребляется словоформа }\end{array}$ & $\begin{array}{c}\text { Кол-во контекстов } \\
\text { (абсолютная частота) }\end{array}$ & $\begin{array}{c}\text { Относительная частота упо- } \\
\text { требления (на 1 млн словоформ) }\end{array}$ \\
\hline $1700-1749$ & - & - & - & - \\
\hline $1750-1799$ & - & - & - & 0,394 \\
\hline $1800-1849$ & 2226 & 5 & 60 & 1,394 \\
\hline $1850-1899$ & 3274 & 45 & 68 & 0,862 \\
\hline $1900-1949$ & 50733 & 49 & 83 & 1,823 \\
\hline $1950-1985$ & 10607 & 59 & 708 & 6,521 \\
\hline $1986-2014$ & 47579 & 435 & & 5 \\
\hline
\end{tabular}


Данные таблицы свидетельствуют о том, что до начала XIX в. данный маркер в текстах не встречается. Его первое вхождение в НКРЯ датируется 1814 г. Средняя относительная частота употребления то бишь меняется с течением времени, достигая максимальных значений во второй половине XX - начале XXI в. Более подробная информация об относительной частоте употребления дискурсивного маркера то бишь представлена на рисунке.
Согласно графику, первая волна роста относительной частоты употребления дискурсивного маркера то бишь приходится на вторую половину XIX в. $\mathrm{B}$ первой половине XX в. его частота снова падает, но во второй половине $\mathrm{XX}$ в. заметен резкий рост частоты встречаемости то бишь. На современном этапе частота употребления данного дискурсивного маркера остается достаточно высокой. Возможно, резкий рост относительной частоты встречаемости

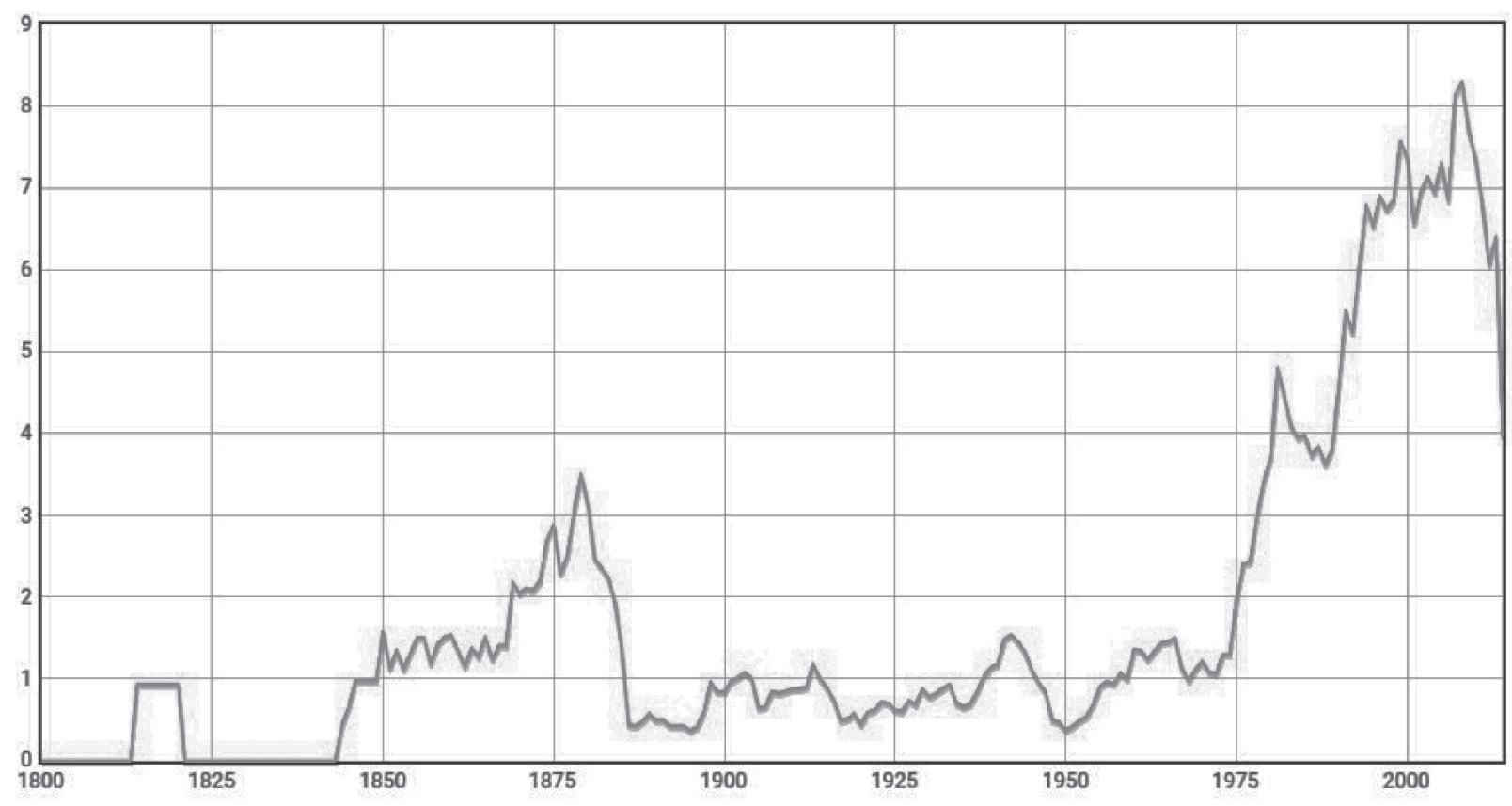

Рисунок. Относительная частота дискурсивного маркера то бишь с 1700 по 2014 г. по данным основного подкорпуса НКРЯ

то бишь объясняется появлением нового модуса коммуникации - компьютерно-опосредованного, который по многим своим свойствам приближается к устной речи. Кроме того, значительная доля контекстов в последнем хронологическом срезе - это фрагменты публицистических текстов, что позволяет говорить о проникновении разговорности в публицистический стиль, его значительной «персонализации» для создания диалога с читателем.

Далее рассмотрим функционирование дискурсива то бишь в выделенных хронологических срезах.

$$
\text { 1800-1849 г2. }
$$

Употребление дискурсивного маркера то бишь не характерно для письменного дискурса первой половины XIX в.: по данным НКРЯ, то бишь встречается всего в пяти контекстах. Во всех найденных нами примерах данная конструкция обладает признаками дискурсивного маркера (в частности, синтаксической и смысловой обособленностью от остальных элементов высказывания) и занимает срединное по- ложение в предложении, что говорит о том, что маркированию подлежит часть того высказывания, в котором используется данный дискурсивный маркер:

А вот, что в запрошлом году умерла, под Болховылм... то бишь под Карачевым, в девках... [И. С. Тургенев. Льгов (1847)]

- Ииь, ловкие какие, - произнес один из рыженьких, - чего захотели, «атусбеш», то бишь... тридцуать пять рублей за лошадь дают... да за эвдаку животину и семьдесят мало... [Д. В. Григорович. Антон-горемыка (1847)]

Все примеры в данном хронологическом срезе это прямая речь персонажей художественных произведений. Интересно, что перед или после то бишь авторы используют многоточие. Очевидно, этот пунктуационный знак отражает паузу в речи, связанную с выбором новых языковых средств. Иными словами, многоточие можно трактовать как способ отражения в письменном тексте ситуации пояснения («атусбеш», то бишь... тридцать пять рублей) или исправления (под Болховым... то бишь под Карачевым). 


\section{$1850-189922$}

Во второй половине XIX в. частота употребления дискурсивного маркера то бишь возрастает. Как и в предыдущем периоде, то бишь употребляется только в функции дискурсивного маркера во всех 60 контекстах. В этом срезе то бишь впервые появляется в начальной позиции в высказывании (8 контекстов), что говорит о том, что новое высказывание нужно говорящему, чтобы уточнить или объяснить предыдущее:

- А как же Феня? - зараз спросили Устинья Марковна и Марья. - Приказала долго жить ... тьфу!!. То бишь, жсива она, а только тово... [Д. Н. МаминСибиряк. Золото (1892)]

Как уже говорилось выше, всего нами было встречено 60 вхождений дискурсивного маркера то бишь в текстах 2-й половины XIX в. Практически все употребления - это устная речь персонажей художественных произведений, часто - просторечная. Что касается способов выделения данного дискурсивного маркера, то они довольно разнообразны (табл. 2).

Наиболее распространенный способ выделения то бишь, занимающего срединное положение в предложении, - знак многоточия до дискурсивного маркера и отсутствие знака препинания после него (20 вхождений):

Едва только вступил он в свою квартиру, как приказал позвать мамку к себе в спальню. - Ну, Авдотья... то бишь Дотюшка. Совсем пора тебе орудовать. [Е. А. Салиас. Аракчеевский сынок (1888)]

Т а б ли и а 2

Способы пунктуачионного оформления дискурсивного маркера то бишь с 1850 по 1899 г. по данным НКРЯ

\begin{tabular}{|l|c|c|}
\hline \multicolumn{1}{|c|}{ Способы пунктуционного оформления то бишь в предложении } & Кол-во контекстов & \% от общего кол-ва контекстов \\
\hline \multicolumn{2}{|c|}{ Дискурсив то бишь занимает начальную позицию в предложении } \\
\hline После то бишь нет знака препинания & 1 & 1,7 \\
\hline После то бишь стоит запятая & 5 & 1,3 \\
\hline После то бишь стоит восклицательный знак & 1 & 1,7 \\
\hline После то бишь стоит знак многоточия & 1 & 1,7 \\
\hline \multicolumn{1}{|c|}{ Дискурсив то бишь занимает срединную позицию в предложении } \\
\hline Перед то бишь стоит запятая, после - знак препинания отсутствует & 8 & 13,3 \\
\hline Перед и после то бишь стоит запятая & 6 & 5 \\
\hline Перед то бишь стоит запятая, после - тире & 3 & 33,2 \\
\hline Перед то бишь стоит знак многоточия, после - знака препинания нет & 20 & 15 \\
\hline Перед то бишь стоит знак многоточия, после - запятая & 9 & 1,7 \\
\hline Перед то бишь стоит знак многоточия, после - знак тире & 1 & 1,7 \\
\hline Перед то бишь стоит знак многоточия, после - знак двоеточия & 1 & 1,7 \\
\hline Перед то бишь нет знака препинания, после - знак тире & 1 & 3,3 \\
\hline То бишь не выделено знаками препинания & 2 & 1,7 \\
\hline Перед то бишь стоит знак тире, после - знак двоеточия & 1 & \\
\hline
\end{tabular}

Также распространены еще 2 способа выделения дискурсива то бишь на письме:

a) перед дискурсивным маркером то бишь используется многоточие, после него - запятая (всего 9 вхождений, что составляет $15 \%$ от общего количества контекстов для данного хронологического среза):

- А вы, князь, шут гороховый... то бишь, я хотел вам предложить один вопрос: приедет ли ваша пьшная родня вас провожать сегодня? [Н. Г. Гарин-Михайловский. Студенты (1895)] б) перед то бишь стоит запятая, а после дискурсивного маркера знак препинания отсутствует (всего 8 вхождений, что составляет $13,3 \%$ от общего количества контекстов для данного хронологического среза). Данный способ выделения дискурсивного маркера то бишь был встречен впервые:

Тетя моя, то бишь сестра двоюродная... нуда это все равно... [П. Д. Боборыкин. Китай-город (1882)]

Отдельно выделим те случаи, когда в состав предложения входит только данный дискурсивный 
маркер, позволяющий говорящему подобрать более точный способ номинации или переключиться на новую тему:

Первым на эстраде явился флейтист чахоточного вида и престарательно проплевал... То бишь! Просвистал пьеску тоже чахоточного свойства; два человека закричали: «Браво!» [И. С. Тургенев. Клара Милич (1882)]

Она изумилась. - То бишь... Что это я? [И. С. Тургенев. Новь (1877)]

Также в данном хронологическом срезе были выявлены случаи, когда запятая использовалась «внутри» дискурсивного маркера. Такое употребление не является приметой авторского стиля или ошибкой, поскольку примеры принадлежат не одному автору:

- То, бишь, не уксус, а прованское масло! [А. П. Чехов. Дуэль (1891)]

Я стала теперь не хозяйка в своем доме?.. То, бишь, выгнали... - И начинала она разводить историю о том, как она, по милости зльх людей и неповиновения детей, дошла до такой бедности. [Ф. М. Решетников. Где лучше? (1868)]

Ах, кабы он был кержак... то, бишь, раскольник... [Ф. М. Решетников. Где лучше? (1868)]

Если спросят: кто ставил? - говорите: разбойник... то, бишь, подрядчик Кудимыч. Вот и всё. [M. Е. Салтыков-Щедрин. Пестрые письма (18841886)]

Такие употребления указывают на то, что то воспринимается не как часть дискурсивного маркера то бишь, а как указательное местоимение, выполняющее функцию подлежащего. Дискурсивную функцию в таких контекстах выполняет только частица бимь.

Данный хронологический срез также отличается разнообразным пунктуационным оформлением дискурсивного маркера то бишь в речи персонажей художественных произведений.

\section{0-1949 г2.}

Хронологический срез 1900-1949 гг. характеризуется спадом относительной частоты употребления то бишь по сравнению с предыдущим периодом (см. табл. 1 и рисунок). Что касается положения то бишь в составе предложения, то, как и прежде, преобладает употребление в середине предложения (80\% контекстов).

Как и в предыдущем хронологическом срезе, в срезе 1900-1949 гг. способы пунктуационного выделения дискурсивного маркера то бишь очень разнообразны. Наиболее частотны случаи (40 \% контекстов), когда перед то бишь стоит запятая, а после знак препинания отсутствует. В 20 \% примеров перед то бишь авторы используют многоточие, при этом после дискурсивного маркера может использоваться еще одно многоточие, запятая либо знак препинания может отсутствовать.

В данном хронологическом срезе мы впервые встретили несколько новых способов выделения дискурсивного маркера то бишь, например, использование двоеточия после дискурсива, занимающего начальную позицию в высказывании:

Tо бишь: «Пел на грех, на беду соловей во саду - песню томную... [И. А. Бунин. Суходол (1911)]

Также на данном хронологическом этапе были выявлены примеры, где дискурсивный маркер то бишь взят в скобки, но знаками препинания не выделен:

«Юбилей - репетиция похорон», сказано про такие юбилеи с надгробныли (то бишь приветственными) речами; а кому же весело присутствовать на репетиции собственных похорон! [Р. В. Иванов-Разумник. Тюрьмы и ссылки (1934-1944)]

В данном хронологическом срезе отмечается орфографическая вариативность: в большинстве случаев то бишь пишется раздельно, однако нами было выявлено 3 контекста, где то бишь пишется через дефис:

Но и тут беда: по одной памяти ничего точного не напишешь, а весь «архив» мой (то есть уцелевшая от разгрома его часть) находится в Мекке, то-бишь - Царском Селе. [Р. В. Иванов-Разумник. Тюрьмы и ссылки (1934-1944)]

Это один прохвессор... то-бишь... клоун в циике спрашивал: какая разница между домом... и барышней!. [Ф. Д. Крюков. Группа Б// «Русские записки», 1916]

Таким образом, данный хронологический срез демонстрирует вариативность в пунктуационном выделении и написании дискурсивного маркера то бимь.

$$
\text { 1950-1985 г2. }
$$

Относительная частота употребления дискурсива то бишь в данном хронологическом срезе продолжает повышаться и составляет в среднем 1,823 вхождений на 1 млн словоупотреблений.

В подавляющем большинстве контекстов данного хронологического среза $(95,7$ \%) то бишь употребляется в середине высказывания. Пунктуационное выделение этого дискурсива не так разнообразно, как в предыдущем периоде. В 77,4 \% случаев перед то бишь ставится запятая, после маркера пунктуационный знак отсутствует. Интересно, что в этом срезе авторы практически не используют двоеточие (2,1%). Ср. несколько примеров:

Мы искали определяющего явление либо предмет слова, а он всячески его избегал, опасался, петлял, как заяц, чтобы, не дай Бог, не столкнуться с волком, то бишь словом. [Владимир Соловьев. Три ев- 
рея, или Утешение в слезах. Роман с эпиграфами (1975-1998)]

Это было естественным для человека его профессии, но неожиданным для такого поселка, то бишь деревни, как Сосновка, где одиноких пассажиров-мужчин городского вида непременно встречали то руководители лесопункта, то поселкового Совета, то школь, больницы или клуба. [Виль Липатов. И это все о нем (1984)]

Тут помогали обмолвки, случайные узнавания, соседские доносы... то бишь, боевые донесения. [А. И. Солженищын. Архипелаг ГУЛаг (1958-1973)]

Написание то бишь через дефис можно встретить и в данном хронологическом срезе (всего выявлено 2 контекста).

До этого он, что называется, «стучался в двери» (то-бишь, в радиотелескопь) астрономов, которые ещзе в начале шестидесятых годов обнаружили в иентральной части Крабовидной туманности переменный радиоисточник малых угловых размеров, особенно интенсивный на низких частотах. [И. С. Шкловский. Взрываюшиеся звезды и их остатки (1981)]

Таким образом, контексты, относящиеся к данному хронологическому срезу, свидетельствуют об определенной стабилизации пунктуационного оформления данного дискурсивного маркера.

\section{6-2014 22}

Частота употребления дискурсива то бишь с 1986 по 2014 г. выросла более чем в 7 раз. Это можно объяснить тем, что для последнего хронологического среза уже доступны данные о компьютерно-опосредованной коммуникации, в которой письменная речь максимально приближена к устной. То бишь активно используется носителями русского языка в новом модусе коммуникации, а также в публицистических текстах. По-прежнему сохраняется тенденция использования то бишь внутри высказывания (86 \% контекстов) и наблюдается относительное разнообразие в его пунктуационном оформлении: дискурсивный маркер чаще всего выделяется запятой (62,3% контекстов). Вторым по частотности является использование то бишь в скобках $(9,2 \%)$.

По неграмотности репортер в очередной раз подменяет понятие "бомонд», то бишь высший свет, пришедшимся к слуху словом «богема», которое переводится как «ияыганщңина» и применимо лишь по отношению к малоимущеей группе нонкомформистов-художников, ведуших асочиальнылй, а нередко и бродяжий образ жизни. [Александр Зябликов. Провинцииальная столица // «Сибирские огни», 2013]

Стало очевидно, что медь - для быдла, то бишь народа, а серебро - для правительства, для господ. [Андрей Левандовский. Безупречный министр // «Знание-сила», 2013]
Если вы проводите правильно индукциюю (а за одну минуту проводить ее - зверство), и на шоке ваша индукция должна проводиться параллельно с противошоковыми мероприятиями, то бишь, с адекватной гемодинамической подпоркой и др. [коллективный. Форум: Натрия оксибутират + Тиопентал (20122013)]

Подводя итог данного этапа исследования, отметим, что дискурсивный маркер то бишь в устной речи персонажей художественных произведений является сигналом разговорного стиля. 2-я половина XX в. это время, когда то бишь начинает использоваться и в публицистических текстах, и в компьютерно-опосредованной коммуникации уже не как примета разговорного стиля, а как дискурсивный маркер, позволяющий говорящему в определенной степени скорректировать свое высказывание.

\section{Функции дискурсивного маркера то бишь}

Вторая часть данного исследования посвящена выявлению и описанию функций дискурсивного маркера то бишь. Очевидно, что функции можно выявить на основе анализа семантических отношений между исходным и повторным способом называния или характеристики объекта референции. Анализ конкорданса показывает, что эти семантические отношения достаточно разнообразны, они не сводятся к припоминанию или поправке оговорки, как на это указывают словари. Напротив, в письменном дискурсе повторная номинация - это всегда целенаправленное действие автора высказывания, позволяющее выразить дополнительные индивидуальные смыслы.

Повторная референция может осуществляться с различными целями. В самом общем виде функция дискурсива то бишь может быть описана как разъясняющая - с его помощью говорящий представляет объяснение того, что имелось в виду:

Жуть, между прочим: вторую неделю пытаемся найти пару качественных дамских кроссовок «не по моде»-то бишь не бельх, не розовых и с простроченным, а не приклеенным носком. [Наши дети: Подростки (2004)]

Такое употребление объясняется потенциальной многозначностью выбранного способа номинации. Стремясь к тому, чтобы гарантировать понимание, говорящий разъясняет смысл, который вкладывался в выбранный способ называния или описания объекта. Выражение «не по моде» может быть понято по-разному, поэтому автор высказывания конкретизирует, какой именно смысл вкладывается в такое описание.

Вариантом такого употребления являются контексты, в которых говорящие разъясняют значение иностранных слов или терминов: 
Нужно упомянуть, что камера имеет не только специиальный режим съемки против света, но и фирменную никоновскую функцию D-lighting (то бишь расширение динамического диапазона), которую можно применять как во время фотографирования, так и после. [Юлия Никитина. Друг неуклюжего снорклера // «Русский репортер», 2013]

В середине октября 2009 года научная печать сообщила, что группа британских и китайских исследователей, проводя раскопки в Северо-Восточном Китае, обнаружила ичелое кладбище - около 20 скелетов - летаюших ящуеров типа птерозавров, но совериенно неизвестного доселе вида, которому они дали название Дарвиноптерус, то бишь «Дарвиново крыло». [Антон Арутюнов. Птеродактиль промежуточный // «Знание-сила», 2012]

- О чем, как не о пирожных!.. Кондитерская "Норд", то бишь "Север", сльххал? С ней вообще легко управляться, - сказал Баев, стягивая с меня одеяло. [Екатерина Заверинева. Высотка (2012)]

Но страхи о глобальной эпидемии, то бишь пандемии, птичьего происхождения тогда оказались преувеличенными. [Эдуард Геворкян. «Птицьь-2»-не по Хичкоку // «Наука и религия», 2011]

Часто объектом объяснения становятся образные выражения, которые употребляются для описания конкретной ситуации. Идиоматичность таких образных выражений позволяет говорящему выражать дополнительные смыслы, но в интересах говорящего (который может не обладать необходимыми фоновыми знаниями) говорящий также называет объект референции, для которого вначале использовалась образная номинация:

И сколь ни храбры были с новым генералом французы, мы перешли Рубикон... то бишь реку Адду. [О. Д. Фори. Михайловский замок (1946)]

В приведенном контексте то бишь вводит в высказывание реальное название реки, чтобы показать, каким образом фразеологическая номинация соотносится с реальностью. Аналогично в следующем контексте фразеологический оборот толкуется применительно к конкретной ситуации.

Ну, а если мальчик мал ростом? Если при всем его старании баскетбольный мяч перебрасывают над его головой? Что ж, такой может «пожинать лавры», то бииь пятерки, не в играх, а, допустим, в гимнастике. [M. Тартаковский. Обыкновенный предмет // «Юность», 1963]

Также в конкордансе представлены контексты, в которых то бишь сигнализирует переход к образному описанию ситуации:

В прихожей, то бишь в «плену», томится Клавдюшка с соседнего двора. [Л. А. Кассиль. Кондуит и Швамбрания (1928-1931)]
Еще одна важная функция то бишь - служить сигналом объяснения индивидуального смысла, который в данном контексте вкладывает в свои слова говорящий:

Так и господин Смуров, несмотря на свою извращенность, выбрал себе в идеаль Варвару: эта смазливая, но достаточно глупая девчонка обручена с инженером Мухиным, так что Смуров вполне гарантирован, что его не привлекут кответственности, - то бишь к венцу, - и не заставят исполнить то, что он никогда бы ни с какой женщиной, будь она самой Клеопатрой, не мог, да и не желал бы исполнить. [В. В. Набоков. Соглядатай (1930)]

Стало очевидно, что медь - для быдла, то бишь народа, а серебро - для правительства, для господ. [Андрей Левандовский. Безупречный министр // «Знание-сила», 2013]

Такие употребления то бишь маркируют контекстную синонимию, т. е. такие способы номинации, которые в языке не обладают сходным значением, но в речи употребляются как равнозначные.

То бишь может вводить в высказывание слово, фонетически похожее на первоначальную номинацию, и служить маркером игры слов:

- Как это тонко, - вспьхнув, сказала сестра Осинина. - Иучено... - прибавила маленькая, остроносая, с темными усиками Гиацинтова: звин-по-малороссийски - звон и название «Звиняч» - одна поэзия... Во всяком случае - звучнее, чем Криво-дуры... то бишь... Криводубы. - Господа, мешаете аппетиту! - с трудом, набитым ртом, сказал Михайльч: - дайте поесть, а потом - филология... [Ф. Д. Крюков. Группа Б// «Русские записки», 1916]

Синонимы с разной стилистической окраской также могут использоваться для уточнения сказанного и создания в высказывании стилистического контраста между нормативной и сниженной номинацией:

Значит, медальонь брали для продажи, как говорят фариовщики, «за бугор», то бишь за границу. [Э. Хруиякий. Осень в Сокольниках (1983)]

Но если вы настаиваете, извольте: в данный момент я иду в уборную, то бишь в сортир. [А. Солженицын. В круге первом, $m$. 1, гл. 1-25 (1968)]

И попадает в богоугодное заведение, которое в народе зовут грубым и изиничным словом трезвяк. То бишь, в вытрезвитель. $B$ заботливые и ласковые руки тамошних тружеников... [Кража на посошок // «Криминальная хроника», 2003.06.10]

Хезитация для подбора необходимого слова достаточно редкие случаи употребления то бишь в XX в.:

Ведь у меня во Ржеве... то бишь... это, как его... у меня в Яицком городке и молеленка в доме 
имеется. [В. Я. Шишков. Емельян Пугачев. Книга третья. Ч. 2 (1934-1945)]

Анализ семантических отношений между первичной и повторной номинацией позволяет говорить о том, что в современном русском языке то бишь уже практически не выполняет функции маркера припоминания или самокоррекции. Его активное использование в письменной речи связано с желанием говорящего внести дополнительный смысл или объяснить, как следует понимать первичную номинацию.

\section{Выводы}

Таким образом, проведенный анализ позволяет говорить о том, что использование дискурсивного маркера то бишь, в XIX в. характерное преимущественно для устной речи, в XX и XXI вв. ею не ограничивается. Резкий рост частоты употребления дискурсива то бишь в НКРЯ может объясняться, во-первых, появлением и активным развитием компьютерно-опосредованной коммуникации, во-вторых, сближением устной и письменной речи, которое отмечается лингвистами в последние годы. На это указывает обилие публицистических текстов в НКРЯ, в которых употребляется то бишь.

С ростом частоты употребления связано многообразие функций дискурсивного маркера то бишь: помимо припоминания (которое в письменном дискурсе отражается графически как хезитация при подборе слова) и самокоррекции данный дискурсив употребляется для объяснения смысла потенциально многозначной номинации, стилистической вариативности в высказывании, комментирования образных способов называния или описания объектов. При этом повторная референция не является избыточной: вводя новые способы номинации или описания, то бишь облегчает понимание высказывания, поскольку говорящий удерживает внимание адресата на важной информации и дополнительно активирует объект в оперативной памяти читателя или слушателя. Все это говорит о том, что дискурсивный маркер то бишь играет важную роль в смысловой организации высказывания.

\section{ЛИТЕРАТУРА}

1. Pragmatic Markers, Discourse Markers and Modal Particles. New Perspectives / ed. by C. Fedriani, A. Sansò. Amsterdam ; Philadelphia : John Benjamins Publishing Company, 2017. 504 p.

2. Викторова Е. Ю. Вспомогательная система дискурса. Саратов : Наука, 2014. 404 с.

3. Шилихина К. М. Изучение дискурсивных маркеров методами корпусной лингвистики // Вестник Воро- неж. гос. ун-та. Сер.: Лингвистика и межкультурная коммуникация. 2015. № 3. С. 120-125.

4. Богданова-Бегларян Н. В. Рефлексив в системе дискурсивных единиц русской устной речи // Мир русского слова. 2015. № 3. С. 11-17.

5. Jucker A. H. Discourse markers in Early Modern English // Alternative Histories of English / ed. by R. Watts \& P. Trudgill. London and New York : Routledge, 2002. Pp. 210-230.

6. Traugott E. C. Constructions in grammaticalization // The Handbook of Historical Linguistics / ed. by B. Joseph \& R. Janda. Oxford : Blackwell, 2006. Pp. 624-647.

7. Шилихина К. М., Смирнова В. В. Историческая динамика семантики и сфера действия дискурсивного маркера «видимо» // Вестник Воронеж. гос. ун-та. Сер.: Лингвистика и межкультурная коммуникация. 2017. № 1. C. $107-112$.

8. Баранов А. Н., Добровольский Д. О. Динамика стиля русской письменной речи XIX века : корпусный эксперимент // Компьютерная лингвистика и интеллектуальные технологии : по материалам ежегод. Междунар. конф. «Диалог» (Москва, 17-20 июня 2020 г.). 2020. Вып. 19 (26). URL: http://www.dialog-21.ru/media/4928/ baranovanplusdobrovol-skijdo-009.pdf

9. Национальный корпус русского языка. URL: http:// www.ruscorpora.ru

10. Фасмер М. Этимологический словарь русского языка. URL: https://lexicography.online/etymology/vasmer/

11. Даль В. И. Толковый словарь живого великорусского языка. URL: https://gufo.me/dict/dal.

12. Современный толковый словарь русского языка / под ред. Т. Ф. Ефремовой. 2000. URL: https://dic. academic.ru/contents.nsf/efremova/

\section{REFERENCES}

1. Pragmatic Markers, Discourse Markers and Modal Particles. New Perspectives. Ed. by C. Fedriani, A. Sansò. Amsterdam / Philadelphia: John Benjamins Publishing Company, 2017. 504 p.

2. Viktorova E. Y. Vspomogatelnaja sistema diskursa [Auxilary system of discourse]. Saratov: Nauka, 2014. 404 p.

3. Shilikhina K. M. Corpus-Based Study of Discourse Markers. In Vestnik VGU. Series: Linguistics and Intercultural Communication. 2015. No. 3. Pp. 120-125.

4. Bogdanova-Beglaryan N. V. Refleksiv v sisteme diskursivnykh edinits russkoj ustnoj rechi [Reflexives in the system of discursive units in Russian oral speech]. In Mir russkogo slova. 2015. No. 3. Pp. 11-17.

5. Jucker A. H. Discourse markers in Early Modern English. In Alternative Histories of English. Ed. by R. Watts \& P. Trudgill. London and New York: Routledge, 2002. Pp. 210-230.

6. Traugott E. C. Constructions in grammaticalization. In The Handbook of Historical Linguistics. Ed. by B. Joseph \& R. Janda. Oxford: Blackwell, 2006. Pp. 624-647. 
7. Shilikhina K. M., Smirnova V. V. Historical Dynamics of Semantics and the Scope of Reference of the Russian Discourse Marker "Vidimo". In Vestnik VGU. Series: Linguistics and Intercultural Communication. 2017. No. 1. Pp. 107-112.

8. Baranov A. N., Dobrovol'skij D. O. Style Dynamics of the Russian Written Speech of the 19th Century: A Corpus Study. In Kompjuternaja lingvistika i intellektual'nye tekhnologii: Po materialam ezhegodnoj mezhdunarodnoj konferentsii "Dialog” (Moscow, June 17th-June 20th, 2020). Vol. 19 (26). 2020. Available at: http://www.dialog-21.ru/ media/4928/baranovanplusdobrovol-skijdo-009.pdf

Воронежский государственный университет

Шилихина К. М., доктор филологических наук, заведующая кафедрой теоретической и прикладной лингвистики

E-mail: shilikhina@rgph.vsu.ru

Ткач И. А., аспирант кафедры теоретической и прикладной лингвистики

E-mail: tkach.irina@list.ru

Поступила в редакиию 13 марта 2020 г.

Принята к публикаџии 15 июня 2020 г.

\section{Для цитирования:}

Шилихина К. М., Ткач И. А. Дискурсивный маркер «то бишь»: пример ранней прагматикализации и современное функционирование // Вестник Воронежского государственного университета. Серия: Лингвистика и межкультурная коммуникация. 2020. № 3. C. 54-62. DOI: https://doi.org/10.17308/lic.2020.3/2933
9. Russian National Corpus. Available at: http://www. ruscorpora.ru

10. Vasmer M. Etymological Dictionary of the Russian Language. Available at: https://lexicography.online/etymology/vasmer/

11. Dal' V. I. Tolkovyj slovar' zhivogo velikorusskogo jazyka [Explanatory Dictionary of the Live Russian Language]. Available at: https://gufo.me/dict/dal

12. Sovremennyj tolkovyj slovar 'russkogo jazyka [Modern Explanatory Dictionary of the Russian Language]. Ed. by T. F. Efremova. Available at: https://dic.academic.ru/ contents.nsf/efremova/

Voronezh State University

Shilikhina K. M., Doctor of Philology, Head of the Theoretical and Applied Linguistics Department

E-mail: shilikhina@rgph.vsu.ru

Tkach I. A., Post-graduate Student og the Theoretical and Applied Linguistics Department

E-mail: tkach.irina@list.ru

Received: 13 March 2020

Accepted: 15 June 2020

\section{For citation:}

Shilikhina K. M., Tkach I. A. The Russian discourse marker "to bish" ("that is"): early pragmaticalizaion and modern usage. Proceedings of Voronezh State University. Series: Linguistics and Intercultural Communication. 2020. No. 3. Pp. 54-62. DOI: https://doi.org/10.17308/lic. $2020.3 / 2933$ 